\title{
Study for Impelementation Safety Patrol and Legal Mandate in SHE Management
}

\author{
Dewi Yustiarini*, Moch Fachri Asikin \\ Department of Civil Engineering Education \\ Universitas Pendidikan Indonesia \\ Bandung, Indonesia \\ *dewiyustiarini@upi.edu
}

\begin{abstract}
Construction service activities are a sector that has a high risk of work accidents compared to other service activities. This is because construction service activities involve many things, including building materials, installations or equipment, labour, and the application of technology in large and complex quantities. The aspects of work accidents that occur are mostly the result of unsafe behaviour and unsafe working conditions or unsafe conditions. Therefore, to minimize any possibility of accidents, safety patrol activities must be carried out. This research stage begins with conducting a literature study and determining the subject matter related to safety patrol activities at contractor $X$. The data needed in this study were obtained from interviews, observation, and documentation data sources. The results of interviews and observations were analysed using qualitative descriptive methods. The results of the analysis show that the implementation of the safety patrol activities on contractor $X$ is good enough because it is in accordance with the applicable legal basis/foundation such as Manpower Regulation Number 5 of 1996 concerning Occupational Safety and Health Management Systems.
\end{abstract}

Keywords—safety patrol, construction, projects

\section{INTRODUCTION}

Based on data from the International Labour Organization (ILO) 2018, every year around 380,000 workers or $13.7 \%$ of the 2.78 million workers who die as a result of work accidents, one of the causes is the low awareness of employers and employees about the importance of implementing SHE (Health and Work safety). According to data from the Employment Social Security Administration (BPJamsostek), the number of work accident cases (KK) from 2016 to date has increased. In 2016 there were 101,368 cases with total claims of Rp 88.44 billion, in 2017 as many as 123,041 cases of KK with total claims of Rp 971.62 billion, in 2018 there were 173,415 cases of KK with total claims of Rp 1.22 trillion and at the end of September 2019 a total of 130,923 households with claims of Rp 1.09 trillion [1].

Work accidents occur as a result of unsafe action and unsafe working conditions or unsafe conditions. Heinrich (1930) in Ramli (2010) reveals that $80-85 \%$ of accidents are caused by unsafe behaviour (unsafe action) such as lack of knowledge, skills, attitudes, fatigue, and boredom, how humans work are not ergonomically equivalent, psychological disorders, and social psychological influences. Meanwhile, the other $15-20 \%$ are caused by poor working conditions or unsafe conditions, such as tools that are not suitable for use and safety devices that do not meet standards [2].

Patrols are a great way to find problems and assess them before work-related losses or accidents and illnesses actually occur. The patrol that is carried out can find the conditions of substandard action and immediately repair it to avoid accidents in the workplace. Safety patrol is an activity of patrolling the implementation of SHE in all areas by the Manager class up together with representatives of trade unions. The patrol area includes all areas of building construction work. The purpose of this comprehensive study is to determine the application of safety patrols in construction projects carried out by contractors based on Minister of Manpower Regulation Number 5 of 1996 concerning Occupational Safety and Health Management Systems.

\section{LITERATURE STUDY}

\section{A. Management System}

The Occupational Safety and Health Management System, hereinafter referred to as the Management System, is part of the overall management system which includes organizational structure, planning, responsibilities, implementation procedures, processes and resources required for the development, implementation, achievement, review and maintenance of safety and health policies work in the context of controlling risks related to manual work activities the creation of a safe, efficient and productive workplace [3].

\section{B. Safety Patrol}

Safety Patrol is an activity carried out by company officers which aims to identify irregularities in the workplace related to HSE aspects before an accident occurs. Frank Bird states that patrol is one of the best ways to find problems and estimate the amount of risk before accidents and losses experienced [2]. The 
risks that exist can occur due to materials, means of production, work, and the workplace environment.

The program for organizing HSE inspections in the workplace has several goals and objectives which can be explained as follows:

- Occupational safety and health inspections as an effort to control, supervise and detect early HSE hazards before accidents and occupational diseases occur.

- Inspections are carried out to ensure that each workplace operates in accordance with statutory regulations, standards, norms, and technical guidelines relating to the OHS sector stipulated by the government and company policies.

- Regular and special inspections can be used as material for discussions with workers regarding HSE issues being faced by the company. The existence of coordination and smooth communication between management and workforce will be able to improve the performance or performance of HSE in the company.

\section{SAFETY PATROL AT CONTRACTOR X}

Based on the results of interviews with HSE, it is known that the contractor started safety patrol activities in 2012. The purpose of safety patrol is to minimize the risk of work accidents that occur in the field. Safety patrol is also used as an evaluation material for the policies implemented by the company as well as the conformity of standard equipment. Safety patrols are conducted every Thursday. The HSE team that carries out safety patrols uses complete PPE and brings some equipment such as daily report ets, cameras to document field findings, and badges as markers of implementing safety patrols. This safety patrol daily report et is for recording findings and then evaluated during the meeting every morning meeting.

Morning meeting which is held regularly every day. Safety patrol starts from a morning meeting called Asakai which is adopted from Japanese which means meeting in the morning. Asakai starts at 7.45 WIB until 8.00 WIB, Asakai starts from Safety. The Asakai forum for Safety starts from 7.45 WIB to 7.50 WIB by discussing findings that have been found at the previous time. The purpose of Asakai is to provide information to all employees about the problem at hand and then discuss it to get the right solution.

In the implementation of the Safety Patrol, what is done is not just going around to make sure the equipment or equipment is up to standard or not. In addition, the safety patrol officer must bring equipment as evidence that there is equipment or equipment that does not comply with the standards set at Contractor $\mathrm{X}$. When carrying out safety patrol, the equipment that must be brought is as follows:

- Camera

- Camera Permission Card
- Badge: Safety Patrol

- Daily Safety Patrol Report

In addition to the equipment that must be carried when carrying out a safety patrol, when doing a patrol around, a safety person must also wear the specified PPE, the PPE that must be worn is as follows:

- Helmet

- Safety Shoes

- Safety Vest (Vest)

- Arm

Follow-up on the findings of the Safety Patrol is a report of the findings in the form of a table which will then be given to the shop so that all employees can find out the findings of the safety patrol and can take corrective action on these findings. The follow-up form of safety findings is a list or form that contains:

\section{A. Register Number}

The registration number is the number of findings that have been found during the patrol by the patrol team in all areas, from the 1st floor to the 13th floor.

\section{B. Patrol Team}

The patrol team is the people who are joined to carry out total 10 people and to look for things that do not comply with existing standards or do not meet existing standards. The patrol team consists of HSE people who are in their respective contractors $\mathrm{X}$

\section{Stop 6 Type}

In order to prevent accidents that result in serious injury or disability, the accidents that have occurred are identified and there are " 6 types of accidents" that often occur and have a high risk of occurrence. Here in after categorized as "6 identified accidents (6 designation accidents)". Activities or procedures to reduce the number of accidents, we call the "6 types of accidents" as STOP 6. STOP 6 stands for: Safety Trimatra O (Zero) accident Project 6 (6 Type Of Accident).

Six accidents identified:

1) A (Actuate): Trapped or caught in the engine.

a) Cause: There is no safety device; Weak function of safety devices; Pay less attention to moving parts; Workspace is narrow so that there is not enough distance between the operator and the machine; Stuck on a rotating engine part; Error in placing the machine work piece; No interlock.

b) Object: An accident when releasing work; Rolled up on a grinding job (grinding); Hit by the rotation/spinning of a long object on the machine being processed; Accidents due to work being processed, grinding stones damaged, tool damage or loss; Accidents that arise when the operator is in "WAIT" 
position; Accidents caused by wrong operation with other operators; Accidents due to residual pressure; Wedged by an automatic delivery vehicle (without people).

2) B (Big heavy): Direct contact with heavy objects.

a) Cause: The hoist, crane, wire, fork were damaged; Limited switch position is too high / up; Lack of equipment to prevent falling from the hanger; There is no clear boundary between a safe location and a work location.

b) Objects: Dropped objects hanging from torn pallets / packages; Sandwiched between the crane and the building / wall; Sandwiched between hanging objects and other objects that are still (not moving); Sandwiched between hanging objects and hanging tools; When operating a heavy object the object is tilted; Tilt during the delivery process with a dolly manually; Falling objects from overhead.

3) $C$ (Car): Direct contact with the vehicle.

a) Cause: Getting stuck on the fork end of the forklift when transporting the pallet; Load spilled due to overload / load; The load was thrown and dropped because the chilt was not fully stepped on; Collision with workers who give cues when working together; Collision / roll over while driving a vehicle at high speed.

b) Object: Tripped by someone's jumping; Tripped over by a pile; Lifted by a forklift; The pallet breaks / collapses due to overload; The fall was due to the tilted position of the load.

\section{4) D (Drop): Dropped.}

a) Cause: Lack of safety equipment for high work locations; Broke safety device to go up/down; Going up/down at inappropriate places; Danger / warning signs are placed in non-strategic places.

b) Object: Fall due to breaking of the rising and falling tools; Fall due to defect; Fall due to working up and down but no equipment to go up or down; Fall because there is no safety fence to prevent falls; Fall due to working in a place where there are no footsteps (steps); Fall while moving to wear seat belts; Fall from folding ladder, upright ladder; Dropped while moving because of the equipment itself.

5) E (Electrical): Electric shock.

a) Cause: Lack of safety equipment when there is a short circuit (short circuit) of machine tools; Poor Arde, an insulator for area welding; Not good cover for the electric charging process in the control board; Work in high electric voltage places; Not wearing proper footwear.

b) Object: Electric shock due to damaged equipment; Electric shock on the panel during wiring; Accidents due to contact with high voltage machinery or equipment; Accidents due to contact with electric leaks in tools and cables that have electric shocks; Fall from a high place due to the electric shock.

\section{6) F (Fire): Direct contact with hot objects.}

a) Cause: Incorrect packing of the conductors of distribution pipes and high temperature machine equipment; Absence of static electric countermeasures from high temperature objects; Leaking of flammable liquid / chemical storage tanks; Exposed to electric sparks on a vital part of the body.

b) Object: Due to hot water, steam; Fall into hot, flammable diesel fuel; Exposed to fire when welding; Exposed to the drying furnace the high heat of the furnace; An explosion occurred while working with flammable gases; There was a vapour and dust explosion; There was an explosion in the reaction of chemicals; There was an explosion from a dangerous object, high pressure gas.

In doing STOP 6 there are several ways or steps that must be done, namely:

- The first step is to analyse/evaluate the workplace to identify weak points and strengths. Then use materials in our workplace to prevent accidents, namely by collecting data related to STOP 6 points such as Job Safety Cards and manual documents to find "Designated Accidents" (identified accidents).

- The main purpose of analysing / evaluating the workplace is to develop and ascertain whether the " 6 types of designation accident" prevention activities can be carried out.

- Comprehensive analysis is carried out by considering various aspects. So that does not mean that "workers evaluate only when an accident has occurred", but every worker must have a strong desire / determination to ensure that "Designated accidents" will not occur in our workplace.

Evaluation is depicted by a circle that is divided into 4 parts, each of which has its own meaning. These meanings are (See Figure 1):

- The diagram shows a percentage of $25 \%$, which means that there are findings but it is only being informed that there has been no action for improvement.

- The diagram shows the percentage of $50 \%$ which means that information has been received and is currently purchasing materials to correct the findings.

- The diagram shows a percentage of $75 \%$, which means that there is already information, materials for repairs have been purchased and are being repaired but not fixed.

- The diagram shows the percentage of $100 \%$ which means that the findings have been corrected and are in accordance with contractor's standards. 


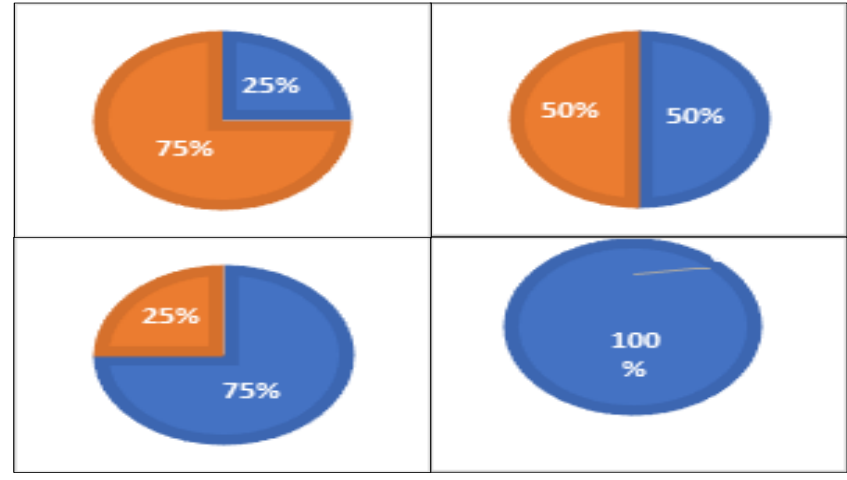

Fig. 1. Evaluation safety patrol contractor X.

Contractor $\mathrm{X}$ is a company engaged in construction management based in Jakarta. In the production process or operation it has a high risk, for that Contractor X committed and determined to achieve high standards by realizing the Zero Accident. In addition, he is also committed to the field of Occupational Health and Safety Management and in the field of Environment and Quality. This commitment is made so that workers, the environment and customers can feel comfortable and satisfied with the services provided. The concern of contractor $X$ in the field of HSE can be seen from the commitment that has been made to realize zero accidents and the implementation of safety patrols to minimize the risk of accidents that will harm both workers and companies. Therefore, safety patrol is carried out regularly.

\section{SAFETY PATROL IMPLEMENTATION WITH MANPOWER REGULATION NUMBER 5 OF 1996}

Contractor $\mathrm{X}$ is a company engaged in construction management based in Jakarta. In the production process or the operation has a high risk, for that Contractor $\mathrm{X}$ is committed and determined to achieve high standards by realizing the Zerro Accident. In addition, he is also committed to the field of Occupational Health and Safety Management and in the field of Environment and Quality. This commitment is made so that workers, the environment and customers can feel comfortable and satisfied with the services provided. Contractor X's concern for the SHE sector can be seen from the commitment that has been made to realize zero accidents and the implementation of safety patrols to minimize the risk of accidents that will harm both workers and the company. Therefore, safety patrols are carried out regularly. All safety patrol activities in Contractor $\mathrm{X}$ are compared according to legal basics and are presented in Table 1 .

TABLE I. SAFETY PATROL CONTRACTOR X AND REGULATION

\begin{tabular}{|c|c|c|}
\hline \multirow{2}{*}{ No. } & \multicolumn{2}{|r|}{ Discussion } \\
\hline & Activity & Description \\
\hline 1. & $\begin{array}{l}\text { Commitment in the field of } \\
\text { SHE Management }\end{array}$ & $\begin{array}{l}\text { The commitments and policies made are in accordance with the Minister of Manpower Regulation No. } 05 \text { / MEN } \\
\text { / } 1996 \text { concerning Occupational Safety and Health Management Systems Chapter III Implementation of } \\
\text { Occupational Safety and Health Systems Article } 4 \text { paragraph } 1 \text { (a) "Companies are required to establish } \\
\text { occupational safety and health policies and ensure commitment to the implementation of Occupational Safety and } \\
\text { Health Management Systems". }\end{array}$ \\
\hline \multirow[b]{2}{*}{2.} & \multirow[b]{2}{*}{ Implementation of safety patrol } & $\begin{array}{l}\text { Safety patrol activities based on the SHEL policy are in accordance with the Minister of Manpower Regulation } \\
\text { No. 05 / MEN / } 1996 \text { concerning Occupational Health and Safety Management Systems }\end{array}$ \\
\hline & & $\begin{array}{l}\text { Safety patrol activities have referred to the Minister of Manpower Regulation No. } 05 \text { / MEN / } 1996 \text { element } 4 \text { of } \\
\text { attachment } 1 \text {, namely "that the company must establish and maintain inspection, testing and monitoring } \\
\text { procedures relating to the goals and objectives of occupational safety and health. }\end{array}$ \\
\hline \multirow{3}{*}{3.} & \multirow{3}{*}{ Patrol safety equipment } & $\begin{array}{l}\text { The use of cameras to document if there are findings that do not match the standards in the field is in accordance } \\
\text { with the Minister of Manpower Regulation No. 05 / MEN / 1996 Annex I Element 3. (2). (2). (d) regarding } \\
\text { "hazard source identification report" and attachment I element 3. (2). (2). (b) non-conformity reporting". }\end{array}$ \\
\hline & & $\begin{array}{l}\text { Daily safety patrol reports are in accordance with the Minister of Manpower Regulation No. 05 / MEN / } 1996 \text { in } \\
\text { appendix I element 3. (2). (1) regarding communication which states that "The company must have a procedure } \\
\text { to ensure that the latest occupational safety and health information is communicated to all parties in the } \\
\text { company". }\end{array}$ \\
\hline & & $\begin{array}{l}\text { The use of PPE in the field is in accordance with Law No. } 01 \text { of } 1970 \text { concerning work safety, article } 12 \text { which } \\
\text { states that "Workers Are Obliged to Wear the Compulsory Personal Protective Equipment". }\end{array}$ \\
\hline 4. & $\begin{array}{l}\text { Follow-up et of safety patrol } \\
\text { findings }\end{array}$ & $\begin{array}{l}\text { The Follow Up et for the Safety Patrol Findings is in accordance with the Minister of Manpower Regulation No. } \\
05 \text { / MEN / } 1996 \text { attachment I element 3. (2). (5) regarding recording and information management which states } \\
\text { that "recording is a means for companies to show the suitability of the application of SMSHE" }\end{array}$ \\
\hline 5. & List of safety patrol findings & $\begin{array}{l}\text { The list of safety patrol findings is in accordance with the Minister of Manpower Regulation No. O5 / MEN / } 1996 \\
\text { attachment I element 3. (2). (5) regarding recording and information management which states that "recording is } \\
\text { a means for companies to show the suitability of the application of SMSHE" }\end{array}$ \\
\hline 6. & $\begin{array}{l}\text { Illustration / Description of } \\
\text { Findings }\end{array}$ & $\begin{array}{l}\text { The illustration / description of the findings is in accordance with the Minister of Manpower Regulation No. 05 / } \\
\text { MEN / } 1996 \text { Annex I Element } 3 \text {. (3). (1) which states that the identification of hazard sources is carried out by } \\
\text { considering; conditions and events that can cause potential hazards, and the types of work-related accidents and } \\
\text { diseases that may occur". }\end{array}$ \\
\hline
\end{tabular}




\section{CONCLUSION}

The results of the analysis show that the implementation of the safety patrol activities on contractor $X$ is good enough because it is in accordance with the applicable legal basis/foundation such as Manpower Regulation Number 5 of 1996 concerning Occupational Safety and Health Management Systems.

\section{REFERENCES}

[1] F.M. Asikin, The Implementation of Safety Patrol Activities in Contractor X Services Prakasa. Bandung: Comprehensive Study/Thesis S1, Indonesian EducationUniversity, 2020.

[2] I. Kristianti and A.R. Tualeka, "Safety Inspection And Knowledge Relationship With Unsafe Action In Rolling Mill Department," The Indonesian Journal of Occupational Safety and Health, vol. 7, no. 3, 2018.

[3] Regulation of The Minister of Manpower Number: PER-05/MEN/1996 about Occupationa Health and Safety Management System. 